\title{
EMPLOYEE PERFORMANCE ASSESSED FROM TURNOVER, WORK CONFLICT, AND THE WORKING ENVIRONMENT
}

\author{
Nita Silviana \\ Universitas Islam Batik, Indonesia \\ nithasilviana241@gmail.com
}

\begin{abstract}
Turnover refers more to the maintenance level of tbsp. Work conflicts lead to the level of problems that occur within the scope of the company. The work environment describes the work atmosphere and the availability of facilities and infrastructure that can directly affect employee performance. The purpose of this study is to prove the results of employee performance in terms of turnover, work conflict, and the work environment of PT. Kinarya Tunas Artha. Using descriptive and quantitative research types. Total population 200 respondents, sample 67 respondents, using multiple linear regression analysis. Research results: $f$ test describes turnover, work conflict \& work environment affect employee performance. While the t-test states that turnover has a positive \& significant effect, work conflict has a negative and significant effect, the work environment has a positive and significant effect on employee performance. The results obtained R2/ coefficient of determination of the effect of turnover, work conflict, and work environment on the performance of $53.5 \%$, the work environment variable becomes dominant because the $t_{\text {count }}$ is the largest.
\end{abstract}

Keywords: Employee Performance; Turnover; Work Conflict; Work Environment

\section{INTRODUCTION}

Employee performance plays an important role for the company because the results of the company's employees' performance can produce high-quality productions according to company expectations. Therefore, performance results greatly determine the level of progress of the company in carrying out the work program that has been determined. Employee performance is the level of work achievement that has high standards and targets in completing work based on their authority and obligations (Mangkunegara, 2017). Every company wants to have employees who can produce an optimal performance to achieve goals. This pandemic will certainly affect employee performance due to various factors.

Turnover refers more to the level of maintenance of human resources in the company, namely reviewing the percentage level of employees who leave the company and new employees. Work conflict leads to the level of problems that occur within the scope of the company and how to resolve conflicts caused by differences in the character of each individual. The work environment describes the work atmosphere and the availability of facilities and infrastructure that can directly affect employee performance. Al Battat et al. (2013) explain that turnover intention is a positive determining factor for turnover.

Turnover is classified into two types, namely: voluntary employee resignation caused by individual wishes, while forced resignation of employees caused by urgent matters or company decisions (Fallis et al., 2014). Conflict is an incompatibility between individuals and other individuals within the scope of the company who are required to share resources with limited availability fairly because each individual has a different status and goals (Rivai, 2013). According to Hasibuan (2011), the causes of problems include differences of opinion, misunderstanding, lack of communication, and sensitive feelings. For companies, the work environment plays an important role in reviewing the continuity of the company's work program and can influence employee performance results. Sedarmayanti (2016) argues that there are potential obstacles in 
creating environmental conditions in the workplace, as follows: Lighting in workspaces, temperature, humidity, air circulation, and noise.

Employee performance according to Indrasari (2017) employee performance is an achievement of the performance of each individual with the capabilities and limits set by the company in achieving goals. Employee turnover according to Robbins \& Judge (2008) is a permanent voluntary resignation (voluntary) or involuntary (involuntary) from an organization. Work Conflict According to Mangkunegara (2017), work conflict is a difference in perception between what other people expect and the reality we expect. It would be nice for the company to be able to resolve conflicts properly because prolonged problems will affect employee performance. Work Environment The work environment is one of the company assets that play an important role in the work activities that are distributed by employees according to the portion, with this a calm, pleasant and serene scope that can encourage the performance of workers (Hasibuan, 2011)

The purpose of this study is to prove the results of employee performance in terms of turnover, work conflict, and the work environment of PT. Kinarya Tunas Artha. Using descriptive and quantitative research types. The hypotheses in this study are:

$\mathrm{H} 1$ : Estimated overall variables $\mathrm{x}_{1}, \mathrm{x}_{2}, \mathrm{x}_{3}$, and $\mathrm{y}$ have a significant effect.

$\mathrm{H} 2$ : Estimated employee turnover and performance have a significant effect

H3: Alleged work conflict on employee performance has a significant effect.

$\mathrm{H} 4$ : Estimated work environment and employee performance have a significant effect

\section{METHODS}

Using descriptive and quantitative. Conducted November 2020 - January 2021 at PT. Kinarya Tunas Artha. The population of this research is all employees of Kinarya Tunas Artha having their address at Ceplukan, Wonorejo, Kec. Gondangrejo, Karanganyar Regency, Central Java, and the population is 200 employees. Determining the number of samples using the Yamane formula resulted in a total sample size of 67 respondents.

\section{RESULT AND DISCUSSION}

Table 1. F Test Analysis

\begin{tabular}{lllccl}
\hline Model & $\mathbf{F}_{\text {count }}$ & $\mathbf{F}_{\text {table }}$ & Sig & Std & Information \\
\hline 1. & 26,286 & 2,74 & 000 & 0,05 & Decent Model \\
\hline \multicolumn{5}{c}{} \\
& \multicolumn{5}{c}{ Source: Processed $(2020)$} \\
\end{tabular}

The result of the table shows that the value of $F_{\text {count }}(26.286)>F_{\text {table }}(2.74)$, it can be concluded that it has a significant effect on the variable turnover, work conflict, and work environment on employee performance.

Table 2. T-Test Analysis

\begin{tabular}{llllll}
\hline Variable & $\mathrm{T}_{\text {count }}$ & $\mathrm{Ttable}_{\mathrm{a}}$ & Sig & Std & Information \\
\hline Turnover & 3,503 & 2000 & 0,000 & 0,05 & Ho rejected \\
Work Conflict & $-5,874$ & 2000 & 0,000 & 0,05 & Ho accepted \\
Work environment & 4,450 & 2000 & 0,000 & 0,05 & Ho rejected \\
\hline \multicolumn{5}{c}{ Source: Processed (2020) }
\end{tabular}

Based on the results table 2, the following results are obtained: In the Turnover variable $(X 1)$ the results of the $t_{\text {count }}(3.503) \geq t_{\text {table }}(2000)$ with a significant $0.000 \leq 0.05$, then the partial test of turnover has a positive \& significant effect on employee 
performance $(Y)$ Kinarya Tunas Artha. In the work conflict $(X 2)$ variable, the results of the $t_{\text {count }}(-5.874)<t_{\text {table }}(2000)$, obtained data sig $0.000<0.05$, so the partial test of work conflict has a negative and significant effect on employee performance (y) Kinarya Tunas Artha. Work environment (X3) obtained results $t_{\text {count }}(4,450) \geq t_{\text {table }}(2000)$, sig value $0,000 \leq 0.05$, the conclusion is that the environmental $t /$ partial test has a positive/significant effect on the performance of employees of Kinarya Tunas Artha.

Table 3. Multiple Linear Regression Test

\begin{tabular}{lccc}
\hline Variable & $\mathrm{B}$ & \multicolumn{1}{c}{$T_{\text {count }}$} & Sig \\
\hline (Constant) & 8,102 & 3,629 & 0,001 \\
Turnover & 0,379 & 3,503 & 0,001 \\
Work Conflict & $-0,306$ & $-5,874$ & 0,000 \\
Work environment & 0,480 & 4,450 & 0,000 \\
$\mathrm{R}^{2}=0,556$ & $\mathrm{~F}_{\text {count }}=26,286$ & $\mathrm{Fsig}=0,000$ & \\
${\text { Adjusted } \mathrm{R}^{2}=0,535}$ & & \\
\hline & Source: Processed (2020) & \\
& $\mathbf{Y}=\mathbf{\alpha} \mathbf{+} \boldsymbol{\beta}_{\mathbf{1}} \boldsymbol{X}_{\mathbf{1}}+\boldsymbol{\beta}_{\mathbf{2}} \boldsymbol{X}_{\mathbf{2}}+\boldsymbol{\beta}_{\mathbf{3}} \boldsymbol{X}_{\mathbf{3}}+\mathbf{e}$ &
\end{tabular}

Interpretation: (1) Constant value of 8,102 indicates that the Turnover, Work Conflict, and Work Environment variables will increase Employee Performance by 8,102; (2) For the Turnover variable, the regression coefficient is positive (0.379). It shows that if the turnover variable can still be controlled, the employee performance at PT. Kinarya Tunas Artha will increase by a ratio of 1: 0.379 with the assumption that conflict decreases and the Work Environment remain; (3) For the Work Conflict variable the regression coefficient is negative $(-0.306)$. This shows that if work conflicts can be resolved properly, the performance of employees at PT. Kinarya Tunas Artha can be improved by comparing the assumption that turnover can be controlled and the working environment is fixed; (4) For the Work Environment (X3) the regression coefficient is positive $(0.480)$. This shows that if the work environment variable is increased, the performance of employees at PT. Kinarya Tunas Artha will increase by a ratio of 1: 0.480 with the assumption that turnover and work conflict can be controlled.

Table 4. Multiple Determination Coefficient Test

\begin{tabular}{lllll}
\hline Model & R & R Square & Adjusted R Square & Durbin-Watson \\
\hline 1 & 0,746 & 0,556 & 0,535 & 2,374 \\
\hline \multicolumn{5}{c}{ Source: Processed (2020) }
\end{tabular}

The test results (R2) in table 4, show an Adjusted R Square number of 0.535 , that the effect of turnover, conflict in the workplace and work environment is $53.5 \%$ on employee performance, while $46.5 \%$ is not included in the study. The effect of turnover/ $x 1$, work conflict / $x 2$, and work environment / x3 on the performance of employees of PT. Performance Buds Artha Obtained $F_{\text {count }}(26.286)>F_{\text {table }}$ (2.74), then Ho is rejected and tested overall has a significant effect. The reason is that the more frequent turnover occurs, the frequent appearance of work conflicts, and the scope of work that does not support work activities will affect employee performance. The effect of turnover (x1) on the employee performance of PT Kinarya Tunas Artha.

There is an acquisition of $t_{\text {count }}(3.503) \geq t_{\text {table }}(2000)$, sig value $0.000<0.05$ means that $\mathrm{HO}$ is rejected, t-test / partial turnover has a positive and significant impact. This proves that if turnover can be controlled properly, the turnover that occurs will not have a bad impact on employee performance at PT. Kinarya Tunas Artha. The research 
shows significant and positive turnover. This research is supported by Asmara (2018), who states that Turnover Intention has a direct/significant effect. It can be concluded that turnover has a direct impact on performance. The reason is that employees make a voluntary turnover intention, it tends to influence the mindset of other employees to leave the company and of course, it can affect work results. Effect of work conflict (x2) on the performance of employees of PT. Kinarya Tunas Artha. In the trust variable, the results of the value of $t_{\text {count }}(-5.874)<t_{\text {table }}(2000)$ with sig $0.000 \leq 0.05, \mathrm{HO}$ is accepted, the $\mathrm{t} /$ partial conflict test has a negative \& significant effect. Besides, it proves that if work conflicts cannot be resolved properly and tend to increase, it will hurt employee performance. The relevant research results are supported by Pramudia et al., (2019) as well as Sulisvi et al. (2019) who report that work conflicts have a negative impact, which is significant for performance. The reason is because of the large problems faced and the conflict is prolonged, the results of employee performance will decrease.

The influence of the work environment $(x 3)$ on the performance of employees of PT Kinarya Tunas Artha. In the confidence variable, the results of the value of $t_{\text {count }}$ $(4.450) \geq t_{\text {table }}(2000)$, sig $0.000<0.05$, that is, Ho is rejected, the t-test: X3 has a positive/significant effect. This proves that adequate scope can boost employee performance. Research based on Utami \& Rahyuda (2019) reported that the work environment has a good impact.

\section{CONCLUSION}

Turnover, Work Conflict, and Work Environment simultaneously have a significant effect on Employee Performance at PT. Kinarya Tunas Artha. Turnover has a positive and significant effect on Employee Performance at PT. Kinarya Tunas Artha. This means that if the turnover rate is low, it will have a positive effect on improving performance. Work Conflict has a negative and significant effect on Employee Performance at PT. Kinarya Tunas Artha. This means that the more frequent work conflicts occur, it will harm employee performance. Work Environment has a positive and significant effect on Employee Performance at PT. Kinarya Tunas Artha. This means that if the company can create a comfortable and safe work environment, it can encourage employee performance.

\section{REFERENCES}

AlBattat, A. R., Som, A. P. M., \& Helalat, A. S. (2013). Overcoming Staff Turnover in the Hospitality Industry using Mobley's Model. International Journal of Learning and Development. https://doi.org/10.5296/ijld.v3i6.4844

Asmara, A. P. (2018). Pengaruh Turnover Intention terhadap Kinerja Karyawan di Rumah Sakit Bedah Surabaya. Jurnal Administrasi Kesehatan Indonesia. https://doi.org/10.20473/jaki.v5i2.2017.123-129

Fallis, A. ., Robbins, S. P., \& Judge, T. (2014). Organizational Behaviour, Global Edition. In Journal of Chemical Information and Modeling.

Hasibuan, M. S. P. (2011). Manajemen Sumber Daya Manusia. Edisi Revisi Jakarta: Bumi Aksara.

Indrasari, M. (2017). Kepuasan Kerja dan Kinerja Karyawan. Yogyakarta: Indomedia Pustaka, 2017.

Mangkunegara, Anwar Prabu. (2017). Manajemen Sumber Daya Manusia Perusahaan. Bandung: PT. In Remaja Rosdakarya.

Pramudia, A., Samdin, Yusuf, Budi, N., Mokodompit, E. A., \& Ramdhani, F. (2019). Pengaruh Beban Kerja dan Konflik Kerja Terhadap Kinerja Karyawan Pada Bank Syariah Mandiri Cabang Kendari. Jurnal Manajemen \& Kewirausahaan. 
Rivai, Veitzhal. (2013). Manajemen Sumber Daya Manusia. Manajemen Sumber Daya Manusia Untuk Perusahaan Dari Teori Ke Praktik.

Robbins, S. P., \& Judge, T. A. (2008). Perilaku Organisasi Jilid II. Salemba Empat.

Sedarmayanti. (2016). Manajemen Sumber Daya Manusia Reformasi Birokrasi Dan Manajemen Pegawai Negeri Sipil. Bandung: PT. Refika Aditama. In Refika Aditama.

Sulisvi, S., Kustiyah, E., \& Widayanti, R. (2019). Analisis Pengaruh Konflik Peran Ganda, Disiplin Kerja, dan Lingkungan Kerja Terhadap Kinerja Karyawan PT. Global Indo Intimates $\mathrm{Di}$ Klaten. Jurnal IImiah Edunomika. https://Doi.Org/10.29040/Jie.V3i02.661

Utami, P. D. P., \& Rahyuda, K. (2019). The antecedents of consumers' attitude and its consequences on online purchase intention. International Research Journal of Management, IT and Social Sciences. https://doi.org/10.21744/irjmis.v6n4.663 